\title{
DATA ENVELOPMENT ANALYSIS (DEA): PENGUKURAN EFISIENSI KINERJA SEKOLAH DASAR
}

\author{
Siti Fatimah ${ }^{1}$, dan Umi Mahmudah ${ }^{2,3}$ \\ ${ }^{1}$ FKIP Universitas Sebelas Maret Surakarta \\ ${ }^{2}$ Pusat Pengajian Informatik dan Matematik Gunaan, Universiti Malaysia Terengganu, \\ ${ }^{3}$ Tadris Matematika Institut Agama Islam Negeri Pekalongan \\ e-mail: stfatimah89@gmail.com¹, u_mudah@yahoo.com²
}

\begin{abstract}
Abstrak: Penelitian ini bertujuan untuk mengukur efisiensi kinerja Sekolah Dasar di DKI Jakarta khususnya kabupaten Jakarta Pusat dengan menggunakan pendekatan data envelopment analysis (DEA). DEA adalah suatu metode nonparametrik untuk mengukur efisiensi suatu unit pengambilan keputusan Decision Making Units (DMU). DEA membandingkan beberapa DMU yang bersifat homogen berdasarkan sejumlah input untuk menghasilkan suatu output yang diharapkan. Penelitian ini menggunakan metode deskriptif dengan menggunakan DMU sebanyak 103 SD Negeridi Jakarta Pusat yang terakreditasi A dengan tiga input dan empat output. Data dianalisis menggunakan aplikasi DEAP versi 2.1 dengan membandingkan model Constant Returns to Scale (CRS) dan model Variable Returns to Scale (VRS). Hasil penelitian menunjukkan bahwa: 1) pada model CRS, terdapat 8 SDN $(7,77 \%)$ yang memiliki kinerja efisien, sedangkan pada model VRS terdapat 14 SDN (13,59\%) yang memiliki kinerja efisien; 2$)$ model VRS lebih baik dibanding model CRS dalam mengukur efisiensi kinerja SD.
\end{abstract}

\section{Kata Kunci: DEA, Efisiensi Kinerja Sekolah, CRS, VRS}

\section{DATA ENVELOPMENT ANALYSIS (DEA): MEASUREMENT OF THE PERFORMANCE EFFICIENCY OF ELEMENTARY SCHOOLS}

\begin{abstract}
This study measures the performance efficiency of elementary schools in Special Capital Region of Jakarta, especially Central Jakarta district by using data envelopment analysis (DEA) approach. DEA is a non-parametric method to measure efficiency of decision making units (DMUs). DEA compares several homogeneous DMUs based on a number of inputs to produce the expected outputs. This study deployed descriptive method by using DMU as many as 103 public elementary schools that were A-accredited with three inputs and four outputs. Data was analyzed using DEAP version 2.1 application by comparing CRS (Constant Returns to Scale) model and VRS (Variable Returns to Scale) model. Results show that: 1) in CRS model, there are 8 public elementary schools (7.77 percent) which have efficient performances while in VRS model there are 14 public elementary schools (13.59 percent) which have efficient performances; 2) VRS model is better than CRS model in measuring the efficiency performance of public elementary schools.
\end{abstract}

Key Words: DEA, Efficiency of School Performance, CRS, VRS

\section{PENDAHULUAN}

Pendidikan adalah salah satu pilar yang penting dalam meningkatkan kualitas sumber daya manusia. Kualitas pendidikan dapat dilihat dari seberapa besar kinerja suatu satuan pendidikan. Pendidikan yang bermutu tidak hanya dilihat dari proses perencanaan dan strategi yang telah dibangun oleh guru dan sekolah, namun terdapat pilar penting yang lain yaitu keselarasan dukungan dari para orang terdekat siswa dan masyarakat (Mustadi dkk, 2016:313).
Data Kementerian Kesejahteraan Rakyat menunjukkan bahwa setiap tahun terdapat 1,2 juta anak lulusan sekolah dasar yang tidak melanjutkan ke jenjang pendidikan menengah (SMP) dan sekitar 1,2 juta anak lainnya putus sekolah (tidak tamat sekolah dasar). Selain rendahnya akses penduduk terhadap pendidikan dasar, isu semakin mahal biaya pendidikan, disparitas mutu pendidikan di wilayah Indonesia barat dan timur, serta disparatis antara desa dan kota juga menjadi hal yang cukup merisaukan (Sinaga, 2009). 
Berdasarkan hasil Programme for International Student Assessment (PISA) tahun 2012, Indonesia berada di peringkat 64 dari 65 negara. Hal ini menunjukkan bahwa mutu pendidikan Indonesia masih rendah, khususnya dalam bidang matematika, sains, dan membaca. Dilanjutkan hasil dari Education For All Global Monitoring Report (EFA-GMR) tahun 2011, Education Development Index/indeks pembangunan pendidikan (EDI) berdasarkan data tahun 2008 adalah 0,934. Nilai ini menempatkan Indonesia di poisi ke 69 dari 127 negara di dunia. Hasil EDI tahun ini mengalami penurunan yang cukup tinggi terutama pada kategori penilaian angka bertahan siswa sampai kelas V SD. Hal ini menunjukkan bahwa pada kategori ini kualitas pendidikan di jenjang pendidikan dasar masih perlu ditingkatkan. Pendidikan ditingkat SD menjadi pondasi pertama atau dasar pendidikan dalam upaya meningkatkan kualitas pendidikan di Indonesia. Hal ini dikarenakan SD adalah satuan pendidikan yang menyelenggarakan proses pendidikan dasar dan mendasari proses pendidikan selanjutnya dengan tujuan memberikan bekal kemampuan dasar membaca, menulis dan berhitung, pengetahuan dan keterampilan dasar yang bermanfaat bagi siswa sesuai dengan tingkat perkembangannya (Disdik.bekasikab.go.id).

DKI Jakarta adalah ibu kota negara RI dan merupakan satu-satunya kota di Indonesia yang memiliki status setingkat provinsi. Jakarta menempati urutan pertama sebagai kota dengan pertumbuhan terpesat di dunia dalam indeks Emerging Cities Outlokk versi A.T. Kearney yang dirilis pada tanggal 15 April 2014 (Tempo.co). Pada tahun 2011 AMH (Angka Melek Huruf) Provinsi DKI Jakarta mencapai 99,15\% dan yang tertinggi adalah Jakarta Pusat (99,53\%). Selain memiliki peresentase AMH tertinggi, Jakarta Pusat memiliki jumlah kepadatan penduduk paling tinggi, yaitu 23.346 jiwa. Namun, jika dilihat dari laju pertumbuhan selama 10 tahun terakhir (2000-2010) Jakarta Pusat menempati posisi yang terendah, yaitu sebesar $0,27 \%$.

Hasil Pusat Data dan Statistik Pendidikan Kementerian Pendidikan dan Kebudayaan tahun 2015 tentang Statistik Sekolah Dasar tahun 2014/2015 menghasilkan data bahwa jumlah siswa sekolah dasar yang putus sekolah di DKI Jakarta sebanyak 6.216 dari 838.426 siswa.Jumlah siswa kelas 6 sekolah dasar di DKI Jakarta adalah 136.359 , namun jumlah lulusan yang dicapai sebanyak 134.142 siswa dan sebanyak 576 siswa kelas 6 putus sekolah. Berdasarkan data tersebut, terdapat 2.217 siswa yang tidak lulus sekolah. Indikator kriteria kelulusan selain nilai UN adalah nilai raport, nilai ujian sekolah, dan perilaku siswa (jogja.tribunnews). Hal tersebut menjadikan acuan bagi satuan pendidikan untuk menentukan siswa yang lulus dan tidak lulus. Aspek kelulusan menjadi satu pedoman dalam meningkatkan kualitas satuan pendidikan, yaitu sesuai dengan standar kompetensi lulusan (SKL).

Berdasarkan beberapa pertimbangan di atas, efisiensi merupakan aspek yang sangat penting dalam manajemen sebuah satuan pendidikan. Ray (1991:1621) mengemukakan bahwa sekolah dikatakan efisien jika ditemukan cara untuk menghasilkan tingkat prestasi siswa yang maksimal dengan sejumlah sumberdaya yang ada untuk digunakan.

Pendidikan yang bermutu atau berkualitas tidak hanya bertumpu pada hasil tetapi menekankan pada proses. Ukuran keberhasilan penjaminan mutu oleh satuan pendidikan terdiri dari indikator proses, output, outcame, dan dampak (pmp.diksamen.kemdikbud.go.id). Menurut BSNP terdapat 8 indikator standar mutu dalam penyelenggaraan pendidikan, yaitu standar kompetensi lulusan, standar isi, standar proses, standar penilaian, standar pendidik dan tenaga kependidikan, standar sarana dan prasarana, standar pengelolaan, dan standar pembiyaan (bsnp-indonesia.org).

Pengukuran efisiensi kinerja menjadi satu hal yang penting karena berkaitan erat dengan kualitas pendidikan. Salah satu pengukuran efisiensi kinerja adalah dengan menggunakan aplikasi DEA (Data Envelopment Analysis). Pengukuran DEA adalah suatu metode yang digunakan untuk mengevaluasi produktivitas dari suatu unit pengambilan keputusan (unit kerja) yang bertanggung jawab menggunakan sejumlah input untuk memperoleh suatu output yang ditargetkan. Secara sederhana, pengukuran dinyatakan dengan rasio antara output dan input yang merupakan satuan pengukuran produktivitas yang dapat dinyatakan secara parsial atau secara total yang dapat membantu menunjukkan faktor input apa yang paling berpengaruh dalam menghasilkan suatu output. Salah satu keunggulan DEA adalah dapat menangani banyak input dan output dan tidak membutuhkan asumsi hubungan fungsional antara variabel input dan variabel output (Dewiyani, 2007:26). Model DEA dibagi 
menjadi dua, yaitu model CCR (Charnes, Cooper, and Rhode, yaitu Constant Returns to Scale; VRS) yang dikembangkan pada tahun 1978 dan model BCC (Banker, Charners, and Cooper, yaitu Variable Returns to Scale, VRS) yang dikembangkan pada tahun 1984. Dalam model ini, untuk setiap entitas pengukuran Decision Making Unit (DMU) dibentuk input dan output yang pembobotnya dapat ditentukan dengan menggunakan Linear Programming.

Penelitian yang menggunakan metode DEA pada institusi pendidikan telah banyak dilakukan oleh para ahli (Carrington, dkk (2005), Kong dan Fu (2012), Demir (2014), Nazarko dan Saparauskas (2014), Mikusova (2015), Goksen, Dogan dan Ozkarabacak (2015). Sementara itu, Agha dkk (2011) mengaplikasikan metode DEA untuk mengevaluasi efisiensi relative dari 30 program studi di Universitas Islam di Gaza (Islamic University in Gaza, IUG) pada periode akademik 2004 sampai 2006. Hasilnya menunjukkan bahwa rata-rata skor efisiensi sebesar 68,5 persen dan terdapat 10 program studi yang memiliki kinerja efisien. Evaluasi program studi menggunakan metode DEA juga dianalisis dalam penelitian yang dilakukan oleh Duguleana dan Duguleana (2015), yang mana menggunakan 30 program studi di Universitas Transilvania. Hasil penelitian ini menyatakan bahwa terdapat 12 program studi beroperasi secara efisien.

Borge dan Naper (2005) menganalisis efisiensi pada sekolah dasar di Norwegia dengan menggunakan nilai-nilai mata pelajaran utama seperti Matematika dan bahasa inggris sebagai variabel output. Hasil penelitian mengindikasikan bahwa rata-rata skor efisiensi sebesar 0.780. Selanjutnya penelitian Lestari dkk (2015) mengukur efisiensi 10 sekolah dasar di kota Malang menggunakan DEA-VRS menghasilkan bahwa terdapat dua sekolah dasar yang berada pada kondisi tidak efisien.

Berdasarkan permasalahan di atas, pengukuran efisiensi kinerja sekolah dasar di DKI Jakarta khususnya SD Negeri di Jakarta Pusat perlu dilakukan guna mengetahui efisiensi kinerja di SD. Dengan mengetahui tingkat efisiensi di sebuah satuan pendidikan dapat dijadikan pedoman atau contoh dalam meningkatkan tingkat efisiensi satuan pendidikan yang lain. Dengan demikian diharapkan mampu memberikan kontribusi dalam meningkatkan kualitas pendidikan di Indonesia pada umumnya dan di DKI Jakarta pada khususnya.

\section{METODE}

Data dalam penelitian diambil dengan metode deskriptif, yaitu metode yang menggambarkan secara sistematis fakta dan karakteristik objek atau subjek yang diteliti secara tepat dan apa adanya. (Sukardi, 2003:157). Unit analisis penelitian ini adalah SD Negeri di provinsi DKI Jakarta dengan sampel Jakarta Pusat. Variabel penelitian terdiri atas variabel input dan variabel output. Variabel input terdiri atas: 1) jumlah total siswa; 2) jumlah guru; 3) jumlah siswa yang mengikuti UN. Variabel output terdiri atas: 1) nilai UN Matematika, IPA, dan bahasa Indonesia; 2) Rata-rata nilai UN. Jumlah SD Negeri yang mengikuti UN pada tahun 2014/2015 berjumlah 227 unit. Data sekolah yang digunakan berjumlah 103 unit dengan pertimbangan nilai akreditasi A. Metode pengumpulan data dilakukan dengan teknik dokumentasi, yaitu mendapatkan data-data yang telah tersedia di website data pendidikan Dinas Pendidikan Pemprov DKI Jakarta. Data dianalisis dengan menggunakan aplikasi DEAP versi 2.1. Model DEA yang digunakan dijelaskan pada persamaan 1 .

Memaksimumkan:

$E b=\frac{\sum_{r=1}^{R} u_{r b} y_{r b}}{\sum_{i=1}^{l} v_{i b} x_{i b}}$

Fungsi batasan

$\frac{\sum_{r=1}^{R} u_{r b} y_{r j}}{\sum_{i=1}^{I} v_{i b} x_{i j}} \leq 1, \forall j, j=1,2,3, \ldots, N$

Dan

$u_{r b}, v_{i b} \geq$ untuk setiap $r, i$ (dimana $r=1,2,3, \ldots, R$ dan $i=1,2,3, \ldots I)$

Keterangan:

$e_{b}$ adalah efisiensi pada unit $b$

$y_{r i}$ adalah kuantitas dari outputr yang diproduksi oleh unit $j=1,2, \ldots, N$

$x_{i j}$ adalah kuantitas dari inputi yang diproduksi oleh unit $j=1,2, \ldots, N$

$u_{r b}$ adalah bobot yang diberikan kepada outputr dengan dasar unit $b$

$v_{i b}$ adalah bobot yang diberikan kepada inputi dengan dasar unit $b$

$e$ bilangan positif sangat kecil 
dimana $u$ dan $v$ adalah variabel-variabel pada masalah dan merupakan konstrain yang lebih besar dari atau sama dengan sebarang bilangan positif kecil e dengan tujuan untuk menghindarkan sebarang input atau input tidak terdefinisikan dalam menentukan efisiensi. Teknik program linear digunakan untuk mencoba membuat efisiensi dari setiap unit sebesar mungkin. Skor 1 mengindikasikan sebuah DMU yang efisien, dan tidak efisien jika skor efisiensi kurang dari 1. Dalam rangka mendapatkan solusi dari persamaan 1 , maka perlu diubah terlebih dahulu dalam bentuk Linear Programming dengan fungsi batasan seperti terlihat pada persamaan 2 .

Memaksimumkan

$$
\sum_{r=1}^{R} u_{r b} y_{r b}
$$

Dengan fungsi batasan:

$$
\begin{aligned}
& \sum_{i=1}^{I} v_{i b} x_{i b}=1 \\
& \sum_{r=1}^{R} u_{r b} y_{r j}-\sum_{i=1}^{I} v_{i b} x_{i j} \leq 0
\end{aligned}
$$

Atau

$$
\sum_{r=1}^{R} u_{r b} y_{r j} \leq \sum_{i=1}^{I} v_{i b} x_{i j}
$$

Tabel 1. Deskriptif Statistik Sampel

\begin{tabular}{lccrr}
\hline Variabel & Minimum & Maksimum & Rata-rata & \multicolumn{1}{c}{ Std. Dev } \\
\hline Variabel Output & & & & \\
B Indonesia & 59.62 & 87.43 & 74.7207 & 5.8291 \\
Matematika & 37.97 & 93.75 & 66.7855 & 13.3522 \\
IPA & 47.27 & 87.5 & 69.2430 & 9.8479 \\
Rata-rata UN & 50.39 & 88.77 & 70.2497 & 9.3322 \\
Variable Input & & & & \\
Peserta UN & 20 & 110 & 52.6796 & 20.9061 \\
Jumlah Guru & 7 & 33 & 14.8155 & 5.7288 \\
Jumlah Siswa & 125 & 779 & 295.4078 & 123.6509 \\
\hline
\end{tabular}

\section{HASIL DAN PEMBAHASAN Penentuan Variabel Input dan Output}

Efisiensi didefinisikan sebagai perbandingan antara output dan input (Lestari, 2015:170). Langkah pertama dalam menggunakan DEA adalah menentukan variabel input dan variabel output. Pengukuran efisiensi sekolah mengacu pada Standar Pendidikan Nasional (SPN).

Variabel input merupakan modal dasar sekolah yang bersifat internal, bersifat fisik dan non fisik, perangkat lunak maupun perangkat keras, yang semuanya dimanfaatkan untuk peningkatan mutu (Lestari, 2015:170). Variabel input dalam pengukuran efisiensi di sekolah dasar di DKI Jakarta Pusat adalah : 1) jumlah total siswa; 2) jumlah guru; 3) jumlah siswa yang mengikuti UN. Penentuan variabel input selain mengikuti SPN, juga menganalisis data mentah tersebut apakah data baik atau tidak baik (outlier). Data yang outlier dihilangkan karena akan memengaruhi hasil efisiensi. Beberapa data yang outlier adalah sarana prasarana yaitu jumlah perpustakaan dan jumlah laboratorium, jumlah kelas, jumlah guru yang PNS/Non-PNS, jumlah rombel (rombongan belajar).

Variabel output adalah faktor yang menggambarkan tingkat ketercapaian sasaran dari hasil suatu proses pendidikan (Lestari, 2015:170). Variabel output difokuskan pada prestasi akademik siswa yang berkaitan dengan kompetensi lulusan (nilai UN). Ray (1991:1621) mengemukakan bahwa sekolah dikatakan efisien jika ditemukan cara untuk menghasilkan tingkat prestasi siswa yang maksimal. Nilai UN pada variabel output dibagi menjadi 3 bagian yaitu nilai UN Matematika, IPA, dan bahasa Indonesia. Gambaran umum sampel data yang digunakan berdasarkan hasil analisis program DEAP seperti pada Tabel 1. 
Penentuan Decision Making Units (DMU)

DMU diartikan sebagai unit yang akan dianalisa dalam pengukuran efisiensi. Jumlah DMU yang digunakan adalah jumlah SD Negeri di Jakarta Pusat yang mengikuti UN pada tahun 2014/2015 yaitu 103 SDN dari 227 SDN. Jumlah DMU yang digunakan hanya 103 SDN dengan pertimbangan yang memiliki nilai akreditasi $\mathrm{A}$.

\section{Perhitungan Skor Efisiensi Relatif dengan Aplikasi DEAP}

Pendekatan DEA digunakan untuk mendapatkan skor efisiensi kinerja SD Negeridi Jakarta Pusatyaitu menggunakan program DEAP version 2.1. Terdapat dua model yang dihasilkan dari program DEAP sebagai perbandingan, yaitu model CRS dan model VRS. Penelitian ini menggunakan asumsi skala VRS dikarenakan model ini secara umum menghasilkan skor efisiensi yang lebih baik daripada model CRS (Banker, Charnes, dan Cooper: 1984). Selain itu model VRS mengasumsikan bahwa DMU tidak atau belum beroperasi secara optimal. Penelitian iniberorientasikan kepada variabelinput, yang berarti bahwa ketika sebuah DMU yang tidak efisien ingin mencapai level yang efisien maka ia perlu mengurangi proporsi variabel input sementara itu proporsi variabel output tetap konstan.

Sebuah DMU yang memiliki kinerja tidak efisien selalu menghasilkan slacks, yakni perbaikan ataupun peningkatan (penambahan variabel output atau pengurangan variabel input) yang diperlukan oleh sebuah DMU untuk mencapai level kinerja yang efisien. Slack hanya ada pada DMU yang tidak efisien pada model CRS maupun model VRS. Apabila salah satu model menghasilkan skor 1 (efisien) maka nilai slack adalah nol. Pada dasarnya slack dapat dilihat sebagai inefisiensi alokatif pada DMU. Perhitungan slack menggunakan metode multi-stage. Multi-stage DEA yaitu mengurutkan program linier yang radial untuk mengidentifikasi titik proyeksi yang efisien, dimana memiliki campuran variabel input dan output yang semirip mungkin dengan titik proyeksi yang tidak efisien (Coelli, T.J. : 1992). Hasil pengukuran efisiensi kinerja SD Negeridi Jakarta Pusatuntuk model CRS dan VRS dapat dilihat pada tabel 2 dan 3 .
Tabel 2. Distribusi Kumulatif Skor Efisiensi Model CRS

\begin{tabular}{cc}
\hline Skor & Jumlah \\
\hline 1.000 & 8 \\
$0.900-0.999$ & 7 \\
$0.800-0.899$ & 11 \\
$0.700-0.799$ & 16 \\
$0.600-0.699$ & 13 \\
$0.500-0.599$ & 20 \\
$0.400-0.499$ & 11 \\
$0.300-0.399$ & 13 \\
$<0.299$ & 4 \\
Jumlah & $\mathbf{1 0 3}$ \\
\hline
\end{tabular}

Berdasarkan tabel 2, Sekolah Dasar Negeri yang memiliki kinerja efisien hanya berjumlah 8 sekolah atau hanya sekitar 7.77 persen sedangkan sisanya memerlukan usaha yang lebih untuk meningkatkan efisiensi kinerja mereka. Berdasarkan penelitian Rosenholts dalam Tony Bush dan Marianne Coleman (2012: 158-159) mengidentifikasi karakteristik sekolah yang tidak efektif yaitu lemahnya visi dimana guru mempunyai sedikit kasih sayang terhadap segala sesuatu, kepemimpinan yang tidak fokus, dan hubungan staf yang disfungsional.SD yang memiliki skor 1 pada hasil analisis adalah SDN PASEBAN 01 PG, SDN SENEN 03 PG, SDN CIDENG 13 PG, SDN KEBON KACANG 05 PG, SDN GAMBIR $01 \mathrm{PG}$, SDN KARET TENGSIN 01 PG, SDN KEMAYORAN 16 PT, dan SDN KRAMAT 05 PG. Kemudian, rata-rata skor efisiensi kinerja SD Negeridi Jakarta Pusatuntuk model CRS sebesar 0.644 dengan standard deviasi sebesar 0.214 . Sementara itu, nilai skor efisiensi paling rendah ialah sebesar 0.246 yaitu pada SDN Bendungan Hilir 01 . Lebih jauh, terdapat 51 SD Negeriyang memiliki skor efisiensi dibawah rata-rata atau sebanyak 49.51 persen dari sekolah yang ada. Berdasarkan deskripsi tahapan diskriminan yang dikenalkan oleh Thanassoulis, Tyson dan Foster (1987) maka dapat disimpulkan bahwa SDN DURI PULO 02 PG semestinya mampu menopang fase aktivitasnya dengan hanya menggunakan 98.2 persen dari sumber daya yang tersedia.

Manakala SDN KRAMAT 08 PG dan SDN PETOJO UTARA 03 PG seharusnya dapat mempertahankan aktivitas sekolah dengan menggunakan input yang tersedia masing-masing 94,7 persen dan 94,5 persen. 
Tabel 3. Distribusi Kumulatif Skor Efisiensi Model VRS

\begin{tabular}{cc}
\hline Skor & Jumlah \\
\hline 1.000 & 14 \\
$0.900-0.999$ & 10 \\
$0.800-0.899$ & 10 \\
$0.700-0.799$ & 16 \\
$0.600-0.699$ & 15 \\
$0.500-0.599$ & 13 \\
$0.400-0.499$ & 11 \\
$0.300-0.399$ & 12 \\
$<0.299$ & 2 \\
jumlah & $\mathbf{1 0 3}$ \\
\hline
\end{tabular}

Dari Tabel 3 dapat dilihat bahwa rata-rata skor efisiensi kinerja SD Negeri di Jakarta Pusat pada tahun 2014 untuk model VRS adalah sebesar 0,683 dengan standar deviasi sebesar 0,222 . Skor efisiensi terendah ialah sebesar 0.255 diperoleh pada SDN Bendungan Hilir 01.

Selainitu, tabel tersebut juga mengindikasikan bahwa sebanyak 47 SD Negeri memiliki kinerja dibawah rata-rata skor efisiensi atau sebesar 44.66 persen. Sementara itu, SD Negeri yang memiliki kinerja efisien sebanyak 14 sekolah atau sebesar 13.59 persen, yaitu SDN MENTENG 01 PG, SDN CIKINI 01 PG, SDN GUNUNG SAHARI UTARA 01 PG, SDN TANAH TINGGI 02 PT, SDN RAWASARI 05 PG, SDN KRAMAT 08 PG, SDN PASEBAN 01 PG, SDN SENEN 03 PG, SDN CIDENG 13 PG, SDN KEBON KACANG 05 PG, SDN GAMBIR 01 PG, SDN KARET TENGSIN 01 PG, SDN KEMAYORAN 16 PT, SDN KRAMAT 05 PG. Berdasarkan deskripsi tahapan diskriminan yang dikenalkan oleh Thanassoulis, Tyson dan Foster (1987) maka dapat disimpulkan bahwa SDN DURI PULO 02 PG semestinya mampu menopang fase aktivitasnya dengan hanya menggunakan 99,7 persen dari sumber daya yang tersedia. Manakala SDN KEMAYORAN 02 PT dan SDN PASEBAN 07 PG seharusnya dapat mempertahankan aktivitas mereka dengan menggunakan input yang tersedia masing-masing sebesar 98 persen dan 96,6 persen. Dari hasil empiris diatas dapat disimpulkan bahwa model VRS adalah lebih baik dibandingkan model CRS pada pengukuran efisiensi kinerja SD Negeri di Jakarta Pusat pada tahun 2014/2015. Gambar 1 menunjukkan perbandingan skor efisiensi model CRS dan VRS.
Gambar 2 menunjukkan hasil slack variabel input dengan metode two stage DEA., yang mana merupakan pengurangan secara proporsional dari variabel input yang digunakan oleh DMU sehingga DMU tersebut dapat mencapai titik yang efisien. Slack hanya ada pada DMU yang memiliki kinerja tidak efisien dikarenakan ini mewakili bagian sisa dari inefisiensi. Apabila sebuah DMU tidak dapat mencapai efisiensi frontier (mencapai target efisiensi) maka slack diperlukan untuk mendorong DMU tersebut agar efisiensi tercapai. Perlu diketahui bahwa slack input dan slack output semuanya bernilai 0 ketika skor efisiensi bernilai 1 baik pada model CRS maupun model VRS.

Berdasarkan Gambar 2,SD yang memiliki skor efisiensi kurang dari 1 tetapi lebih dari 0 , mereka diidentifikasi sebagai SD yang memiliki kinerja tidak efisien. Sekolah-sekolah tersebut dapat meningkatkan kinerja efisiensi atau mengurangi inefisiensi secara proporsional dengan cara mengurangi input. Sebagai contoh, pada model CRS, SDN DURI PULO 02 PG dapat meningkatkan efisiensinya dengan mengurangi input sebesar 1.8 persen. Gambar 2 juga mengindikasikan bahwa SDN DURI PULO 02 PG perlu mengurangi jumlah siswa yang mengikuti UN yaitu sekitar 10 siswa. Kemudian, pada model VRS, SDN DURI PULO 02 PG perlu mengurangi variabel input sebesar 0.3 persen untuk mencapai titik yang efisien. Sedangkan SDN KRAMAT 08 PG dapat meningkatkan kinerjanya secara efisien dengan mengurangi jumlah input sebesar 5.3 persen.

Hal ini sejalan dengan penelitian Kecek dan Demirag (2016) menginvestigasi 10 sekolah dasar di Kutahya, sebuah provinsi di Turki, untuk mengkur efisiensi relatif menggunakan pendekatan DEA dengan tiga input dan dua output. Hasil menunjukkan bahwa terdapat 4 sekolah dasar dengan kinerja yang efisien sementara 6 SD perlu meningkatkan kinerjanya untuk mencapai level efisiensi yang maksimal. Lestari dkk (2015) melakukan pengukuran efisiensi 10 sekolah dasar dengan metode DEA-VRS. Penelitian tersebut menghasilkan temuan 8 sekolah dasar (SD) di kota Malang berada pada kondisi efisiensi sedangkan 2 SD tidak efisien. Sekolah Dasar yang tidak efisien dinilai kurang mampu memanfaatkan sumber daya yang ada untuk bisa menghasilkan output yang maksimal yaitu kegiatan belajar mengajar, manajemen pendidikan, buku dan saran prasarana, fisik dan penampilan sekolah yang baik, dan partisipasi aktif masyarakat. 


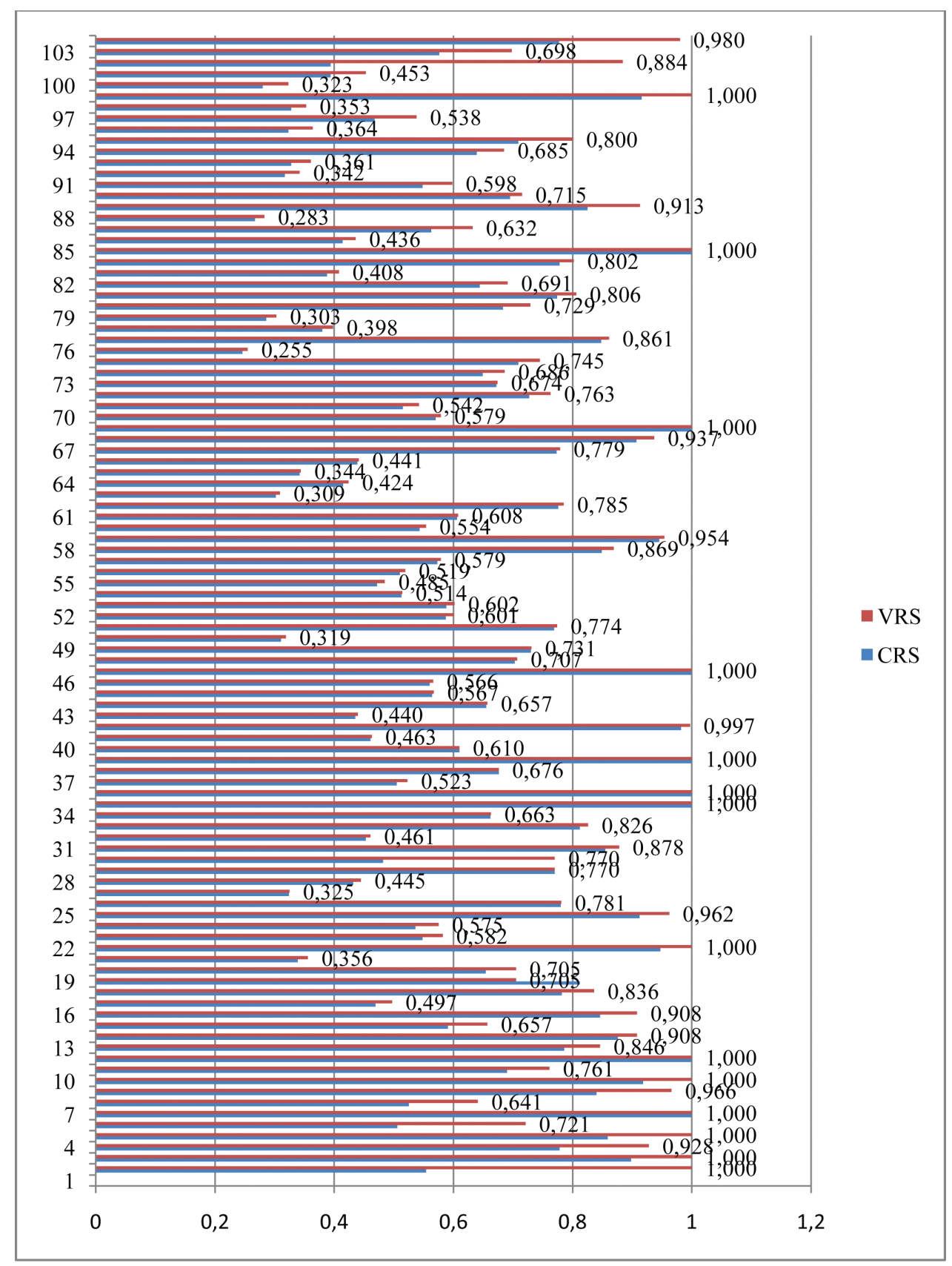

Gambar 1. Skor Efisiensi Model CRS dan Model VRS

Kegiatan belajar mengajar menjadi salah satu faktor yang berpengaruh dalam peningkatan mutu pendidikan di sekolah. Bush dan Coleman (2012:159) menjelaskan beberapa praktik kelas yang tidak efektif yaitu pendekatan pengajaran yang tidak konsisten, kurangnya tantangan, rendahnya tingkat interaksi guru dan murid, tingginya tingkat kegaduhan dalam kelas, dan sering munculnya kritik dan feedback negatif. Hal ini memberikan dampak yang kurang baik dalam meningkatkan kualitas pendidikan di sekolah.

Berdasarkan gambar 2 dapat dilihat bahwa slack untuk semua variabel input bernilai 0 , hal ini dikarenakan skor efisiensi SDN KRAMAT 08 PG pada model VRS adalah 1 yang berarti DMU ini adalah efisien. Sementara itu, SDN PETOJO UTARA 03 PG dapat meningkatkan efisiensi kinerjanya dengan cara mengurangi variabel input sebesar 5.5 persen pada model CRS dan sebesar 4.6 persen pada model VRS. Dari gambar 2 diketahui bahwa DMU ini dapat meningkatkan kinerjanya hingga mencapai efisien dengan mengurangi jumlah peserta UN sekitar 17 siswa dan mengurangi total siswa sekitar 14 siswa.

Berdasarkan data dari Kemdikbud (2014) rasio ideal siswa di sekolah dasar dalam satu kelas 


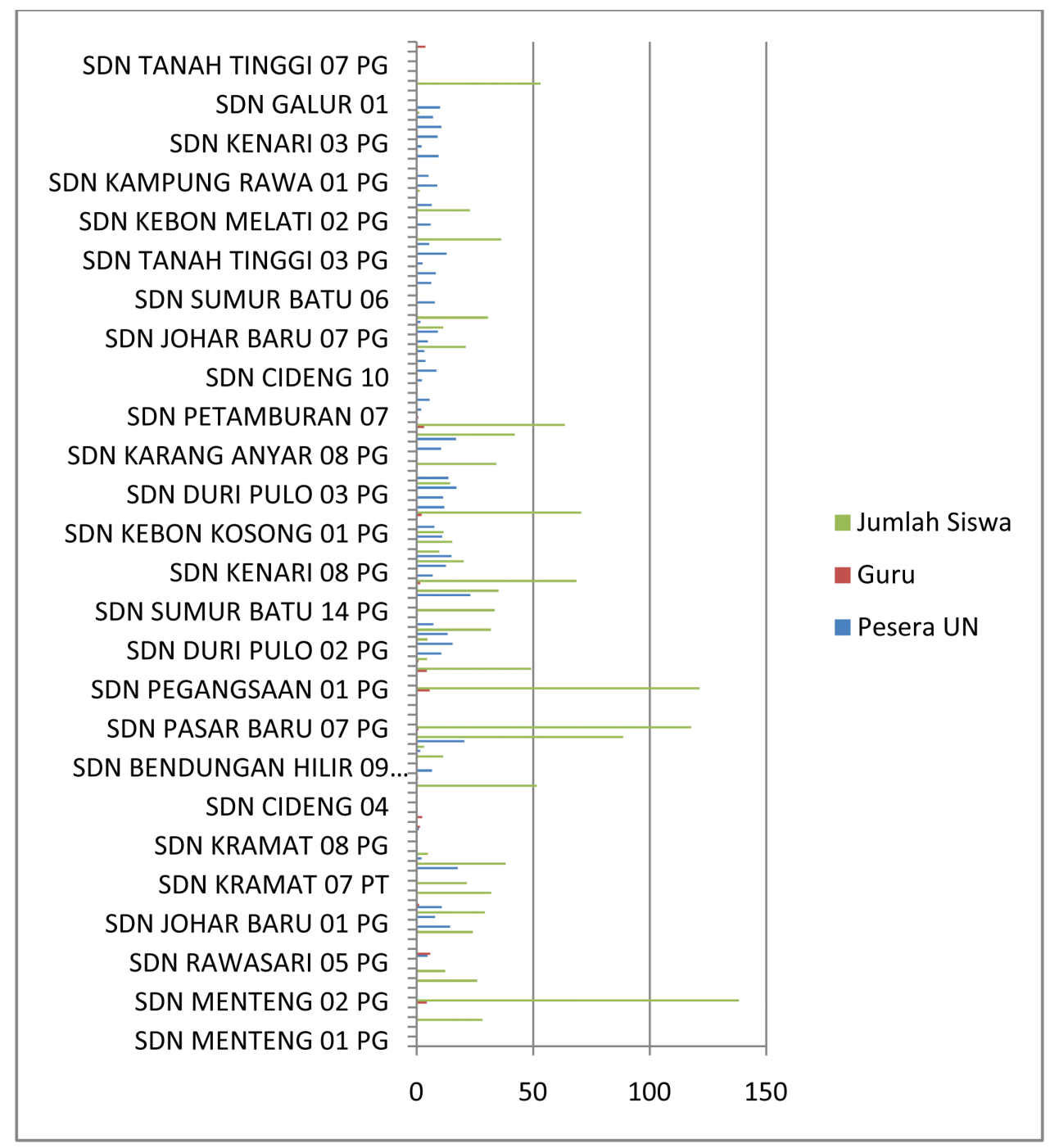

Gambar 2. Hasil Slack Variabel Input

adalah 32 siswa. Hal ini seharusnya menjadi acuan bagi satuan pendidikan tingkat sekolah dasar dalam mewujudkan sekolah yang efektif ditinjau dari rasio kelas dan siswa. Diketahui bahwa jumlah siswa yang mengikuti UN di SDN PETOJO UTARA 03 PG tahun 2014/2015 berjumlah 49 siswa, berdasarkan analisis bahwa SDN PETOJO UTARA 03 PGharus mengurangi 17 siswa agar SD tersebut memiliki kinerja yang efisien.

Manajemen peserta didik menjadi salah satu faktor yang penting dalam meningkatkan kualitas pendidikan.Hal ini tujuan dari manajemen peserta didik adalah mengatur kegiatan-kegiatan peserta didik agar kegiatan tersebut menunjang proses pembelajaran di lembaga pendidikan sehingga proses pembelajaran di lembaga tersebut dapat berjalan lancar, tertib, dan teratur sehingga dapat memberikan kontribusi bagi pencapaian tujuan sekolah pada khususnya dan tujuan pendidikan secara keseluruhan pada umumnya (Tim Dosen Administrasi Pendidikan UPI, 2014: 2016).

Selain menekankan pada jumlah peserta didik, penelitian ini menekankan pada jumlah guru di sekolah dasar. Manajemen tenaga pendidik dan kependidikan merupakan faktor penting dalam meningkatkan kualitas pendidikan. Hal ini dikarenakan, manajemen tenaga pendidik dan kependidikan bertujuan untuk mengarahkan satuan pendidikan pada pembangunan pendidikan yang bermutu, handal, produktif, kreatif, dan berprestasi (Tim Dosen Administrasi Pendidikan UPI, 2014: 231). Seorang guru harus memiliki kompetensi yang baik dalam mewujudkan pendidikan yang berkualitas, yaitu kompetensi pedagogi, kompetensi profesional, kompetensi sosial, dan kompetensi kepribadian. Selain itu, seorang guru memiliki kewajiban dalam menciptakan suasana pendidikan yang bermakna, menyenangkan, 
kreatif, dinamis, dan dialogis; mempunyai komitmen untuk meningkatkan mutu pendidikan, dan memberi teladan dan menjaga nama baik satuan pendidikan.

Penelitian Zhang (2010) yang telah menginvestigasi efisiensi 140 sekolah dasar di Taiwan menggunakan metode two-stage DEA dimana sekolah dasar dan karakteristik siswa dijadikan sebagai variabel lingkungan (environmental variables), hasil menunjukkan bahwa sekolah yang berukuran kecil memiliki skor efisiensi terbesar. Kemudian, rata-rata skor efisiensi baik pada model CRS maupun pada model VRS adalah berbeda pada setiap tahapan dan ukuran sekolah.

Cukup banyak faktor yang berperan dalam keberhasilan sekolah dasar yang salah satunya adalah kepemimpinan kepala sekolah dasar. Karakteristik sekolah dasar yang baik adalah: 1) Kepemimpinan kepala sekolah yang memiliki tujuan; 2) keterlibatan kepala sekolah; 3) keterlibatan pegawai sekolah di dalam perencanaan; 4) konsistensi, keberlanjutan, dan keamajuan di dalam kegiatan pengajaran; 5) pendekatan pembelajaran yang terstruktur; 6) pengajaran yang menantang secara intelektual; 7) lingkungan yang berpusat pada pekerjaan dan iklim kerja yang positif; 8) tugas yang terdefinisi secara jelas; 9) komunikasi yang baik antara guru dan siswa; 10) catatatan tertulis; 11) keterlibatan orang tua dan masyarakat; 12) pekerjaan yang ditunjukkan dan bernilai (Marini, 2014: 78).

Berdasarkan hasil analisis, salah satu sekolah dasar yang menunjukkan kinerja efisien adalah SD Negeri Menteng 01 PG Jakarta Pusat. Berdasarkan data yang diperoleh dari kemdikbud SDN Menteng 01 PG memiliki fasilitas sekolah yang memadai. Sebagai contoh memiliki 13 ruang kelas, memiliki 2 laboratorium, 1 perpustakaan, akses internet, dan 2 sanitasi siswa. Meskipun sarana dan prasarana dalam data analisis tidak digunakan dikarenakan data outlier, namun sarana dan prasarana menjadi satu hal yang penting dalam meningkatkan efisien kinerja, salah satunya adalah tersedianya sanitasi siswa. Lestari (2015) dalam penelitiannya menghasilkan bahwa ketersediaan fasilitas sanitasi siswa menjadi item yang paling berpengaruh kedua setelah komponen kegiatan belajar mengajar.

SD Negeri Menteng 01 PG Jakarta Pusat yang menjadi salah satu sekolah yang memiliki kinerja efisien berdasarkan analisis DEA selain memiliki fasilitas memadai, juga merupakan salah satu sekolah yang dijadikan percontohan dalam penerapanan kurikulum 2013. Hal ini membuktikan bahwa SDN Menteng 01 PG Jakarta Pusat memiliki kualitas yang baik. Kriteria sekolah yang dijadikan sebagai percontohan penerapan kurikulum 2013 adalah akreditasi dan sekolah mandiri (cnnindonesia.com) dilanjutkan selain kedua hal tersebut kriteria penunjukkan sekolah yang menerapkan Kurikulum 2013 adalah sekolah eks RSBI (Rintisan Sekolah Berstandar Internasional) (tribunnews.com). SDN Menteng 01 PG Jakarta Pusat telah menggunakan Kurikulum 2013 sehingga dapat dilihat bahwa pembelajaran pada Kurikulum 2013 harus menggunakan pendekatan saintifik, artinya pengajar harus mampu menggunakan berbagai model pembelajaran saintifik dalam pembelajaran. Hal ini tentu memberikan dampak yang baik dalam meningkatkan prestasi belajar siswa. Hal ini sesuai dengan penelitian Lestari (2015) dalam penelitiannya yang mengukur efisien kinerja sekolah dasar dengan menggunakan DEA menghasilkan bahwa kegiatan belajar mengajar di kelas menjadi item pertama yang paling berpengaruh dalam meningkatkan efisien kinerja sekolah.

Kualitas dan standar sebuah satuan pendidikan dinilai dari infrastruktur fisik dimana terdapat seluruh fasilitas yang tersedia untuk siswa di sekolah. Sebuah sekolah dasar yang efektif dicerminkan dari adanya penampakan fisik yang positif dari sekolah tersebut. Marini (2014:28) menjelaskan prinsip-prinsip dalam merencanakan bangunan sekolah dasar, yaitu: kecukupan kurikulum, keselamatan dan kesejahteraan, koordinasi interfungsional, efisiensi dan kesatuan, keindahan, adaptabilitas, pembuatan keputusan, dan ekonomis. Berdasarkan permendiknas No 24 tahun 2007 tentang standar sarana dan prasarana, di sekolah dasar sekurang-kurangnya memiliki prasarana ruang kelas, ruang perpustakaan, laboratorium IPA, ruang pimpinan, ruang guru, tempat beribadah, ruang UKS, jamban, gudang, ruang sirkulasi, dan tempat bermain/olahraga.

\section{SIMPULAN}

Berdasarkan temuan dan analisis data temuan dapat disimpulkan sebagai berikut. 1) Pada model CRS, terdapat 8 SD Negeri di Jakarta Pusat $(7,77 \%)$ yang memiliki kinerja efisien, sedangkan pada model VRS terdapat 14 SD Negeri (13,59\%) yang memiliki kinerja efisien. 2) Model VRS lebih baik dibanding model CRS dalam 
mengukur efisiensi kinerja SD Negeri di Jakarta Pusat. 3) Jumlah guru dan siswa serta nilai UN menjadi faktor yang penting dalam meningkatkan kinerja efisien sekolah dasar.

\section{UCAPAN TERIMA KASIH}

Tim peneliti menyampaikan ucapan terima kasih kepada Pemprov DKI Jakarta yang telah memfasilitasi data sekunder terkait dengan data pendidikan di DKI Jakarta. Ucapan terima kasih disampaikan pula kepada Ketua Redaktur dan Staf Jurnal Cakrawala Pendidikan yang telah bersedia menerbitkan artikel ini.

\section{DAFTAR PUSTAKA}

Agha, S.R., Kuhail, I., Abdelnabi, N., Salem, M. \& Ghanim, A. 2011. "Assessment of Academic Deparments Efficiency Using Data Envelopment Analysis". Journal of Industrial and Management, 4(2), hlm. 301-325.

Banker, R.D., Charnes, A., \& Cooper, W.W, 1984, "Some Models for Estimating Technical and Scale Inefficiencies in Data EnvelopmentAnalysis", Management Science, 30(9), hlm.1078-1092.

Bappenas, 2013, Profil Pembangunan DKI Jakarta. http://simreg.bappenas.go.id/document/Profil/Profil\%20Pembangunan $\% 20$ Provinsi\%203100DKI\%202013.pdf, diunduh 22 Oktober 2016.

Borge, L.E. \& Naper, L.R. 2005, Efficiency Potential and Efficiency Variation in Norwegian Lower Secondary Schools. Working Paper Series No 12/2005 Department of Economics, Norwegian University of Science and Technology, Trondheim, Norway. http://www.diva-portal.org/smash/get/ diva2:126049/FULLTEXT01.pdf.

BSNP, Standar Nasional Pendidikan, http://bsnpindonesia.org/?page_id $=245$, diunduh 22 Oktober 2016.

Carrington, R., Coelli, T.J., \&Rao, D.S.P. 2005, The Performance of Australian Universities: Conceptual Issues and Preliminary Results. Australian Economic Papers, 24, hlm. 145-163.
Charnes, A., Cooper, W.W., \& Rhodes, E. 1978, "Measuring the Efficiency of Decision Making Units". European Journal of Operational Research, 2, hlm. 429-444.

Coelli, T.J. 1992, “A Computer Program for Frontier Production Function Estimation: FRONTIER, Version 2.0", Economics Letters, 39, hlm. 29-32.

Demir, E., 2014, "A Comparison of Classical and Fuzzy Data Envelopment Analysis in Measuring and Evaluating School Activities". Turkish Journal of Fuzzy Systems 5(1), hlm. 37-58.

Dewiyani, 2007, “Mengukur Efisiensi Kinerja Program Studi dengan Menggunakan Data envelopment Analysis (DEA)". Dalam SNASTI, Prosiding Seminar Nasional Sistem dan Teknologi Informasi, hlm. 25-29.

Dikdasmen, 2016, Petunjuk Pelaksanaan Penjaminan Mutu Pendidikan Oleh Satuan endidikan, http://pmp.dikdasmen.kemdikbud.go.id/files/docs/03.pdf, diunduh 22 Oktober 2016.

Disdikpora, 2014, Kualitas Pendidikan Indonesia Rangking 69 Tingkat Dunia, http:// disdikpora.palangkaraya.go.id/berita-160 -kualitas-pendidikan-indonesia-ranking69-tingkat-dunia.html, diakses 22 Oktober 2016.

Duguleana, L. \& Duguleana, C. 2015, Data Envelopment Analysis for the Efficiency of Academic Departments. Bulletin of the Transilvania University of Brasov, 8(57), hlm. 453-468.

Goksen, Y., Dogan, O. \& Ozkarabacak, B. 2014,A Data Envelopment Analysis for Measuring Efficiency of University Departments. Procedia Economics and Finance, 19, hlm.226-237.

Isa, Muzakar. 2009. "Efisiensi Teknik Pendidikan di Kota Surakarta: Aplikasi Data Envelopment Analysis (DEA)", dalam BENEFIT, Jurnal Manajemen dan Bisnis, 13 (1), hlm. 14-22. 
Kecek, G. \& Demirag, F. 2016, "Measurement of the Relative Efficiency of the Primary Schools in Kutahya by Data Envelopment Analysis". International Journal of Business and Social Science, 7 (4), hlm.265276.

Kong, W.H. \& Fu, T.T., 2012,Assessing the Performance of Business Colleges in Taiwan using Data Envelopment Analysis and Student Based Value-Added Performance Indicators. Omega, 40, hlm.541-549.

Kopertis, 2013, Kemampuan Matematika dan Sains di Urutan ke 64 dari 65 Negara, http://www.kopertis 12.or.id/2013/12/05/ skor-pisa-posisi-indonesia-nyaris-jadi-juru-kunci.html, diunduh 22 Oktober 2016.

Lestari, Karina Dwi. 2015. "Analisis Tingkat Efisiensi Sekolah Dasar di Kota Malang Menggunakan DEA", Jurnal Rekayasa dan Manajemen Sistem Industri, Vol. 3 (1), hlm. 166-177).

Marini, Arita. 2014. Manajemen Sekolah Dasar, Bandung: Rosda.

Mikusova, P., 2015, An Application of DEA Methodology in Efficiency Measurement of the Czech Public Universities. Procedia Economics and Finance, 25, hlm.569-578.

Mustadi, Ali. Dkk. 2016. "Peran Komite Sekolah dalam Peningkatan Mutu Pembelajaran di Sekolah Dasar", dalam Cakrawala Pendidikan, Jurnal Ilmiah Pendidikan, XXXV (3), hlm. 312-321.

Nazarko, J. \& Saparauskas, J. 2014, “Application of DEA Method in Efficiency Evaluation of Public Higher Education Institutions". Technological and Economic Development of Economic, 20 (1), 25-44.

Purnama, Angga. 2015. Indikator Kelulusan Siswa, http://jogja.tribunnews.com/2015/05/15/ ini-indikator-kelulusan-siswa-smasmkdan-ma, diunduh 13 April 2016.
Pusat Data dan Statistik Ketementerian Pendidikan dan Kebudayaan, 2014, Profil Dikdasmen Tahun 2014, http://sdm.data. kemdikbud.go.id/upload/files/ Profil\%20 Dikdasmen\%202014.pdf. Diunduh 05 April 2017.

Ray, S.C, 1991, "Resource-Use Efficiency in Public School: A Study Connecticut Data", Management Science, 37 (12), hlm. 16201628.

Sinaga, Ronny Dicky Wijaya. 2009. "Pengukuran Kinerja Pembangunan Sektor Pendidikan Dasar di Indonesia”, Populasi, 19 (2), hlm. 144-155.

Sukardi, 2003, Metodologi Penelitian Pendidikan, Jakarta, Bumi Aksara.

Tempo, 2014, Jakarta: Kota dengan Pertumbuhan Terpesat di Dunia, https://m.tempo.co/read/ news/2014/04/27/083573662/jakarta-kotadengan-pertumbuhan-terpesat-sedunia, diunduh 22 Oktober 2016.

Tim Dosen Administrasi Pendidikan UPI, 2014, Manajemen Pendidikan, Bandung: Alfabeta.

Thanassoulis E., Dyson, R.G. \& Foster, M.J, 1987, "Relative efficiency assessments using data envelopment analysis: an application to data on rates departments". Journal of Operational Research, 38, hlm. 397-412.

Zhang, Liang-Cheng. 2010, Measuring Elementary School Efficiency in Taipei, Taiwan: Two-Stage Data Envelopment Analysis. Paper presented at the $35^{\text {th }}$ American Education Finance Association Annual Conference on March 18-20 $0^{\text {th }}, 2010$, Richmond, VA.http://publikasi.data.kemdikbud.go.id/ uploadDir/isi_6258FADE-7AA4-49D79626-AD2A921A3013_.pdf, diakses 22 Oktober 2016. 